\title{
Licencias cartográficas, juegos de escala, fronteras difusas. La publicación de planos callejeros de una ciudad en expansión
}

\author{
Cartographic licenses, scale games, imprecise frontiers. Street map publishing for \\ an expanding city
}

\section{Graciela Favelukes \\ grafave@yahoo.com.ar}

CONICET - Instituto de Arte Americano e

Investigaciones Estéticas "Mario J. Buschiazzo”, Facultad de Arquitectura, Diseño y Urbanismo, Universidad de Buenos Aires, Argentina

Recepción: 20 Julio 2020

Aprobación: 07 Septiembre 2020

Publicación: 02 Noviembre 2020

Cita sugerida: Favelukes, G. (2020). Licencias cartográficas, juegos de escala, fronteras difusas. La publicación de planos callejeros de una ciudad en expansión. Geograficando, 16(2), e081. https:// doi.org/10.24215/2346898Xe081
Resumen: La expansión de la ciudad durante el siglo XIX amplió notablemente la producción y circulación de planos callejeros. En ese universo visual novedoso se pusieron en juego alternativas gráficas distintas de los procedimientos definidos en las instituciones cartográficas estatales. En este artículo presentamos de manera exploratoria algunas de esas alternativas sobre la base de planos de Buenos Aires. Nos interesa resaltar la amplia paleta de soluciones gráficas, visuales y editoriales utilizadas para dar a conocer las formas de orientarse en la ciudad. Revisamos, en primer lugar, los formatos y marcos de producción de los mapas callejeros en relación con la cultura impresa y visual del período. En segundo lugar, observamos los métodos utilizados para trazar la silueta de la ciudad y su articulación con las tensiones inherentes entre el espacio delimitado administrativamente y el crecimiento de ocupación urbana. En tercer lugar, hacemos foco en algunas innovaciones y exploraciones visuales que ofrecen soluciones a los dilemas de la concentración de datos en espacios limitados, pero a la vez espacios de juegos figurativos que, proponemos, fueron parte del despliegue urbano.

Palabras clave: Mapa callejero, Cartografía, Historia urbana, Mercado editorial.

Abstract: Urban expansion during the nineteenth century drastically increased production and circulation of street maps. In this new visual universe, various graphic alternatives came into play, most of them different from procedures sanctioned by State cartographic institutions. In this article, we explore some of these alternatives, based on Buenos Aires maps. Particularly, we aim to point out the wide array of graphic, visual and editorial solutions set in motion as aids to guide oneself in the city. Firstly, we inspect the diverse formats and production frameworks of these street maps, in relation with the print and visual culture of the time. Secondly, we observe the methods used to display the urban planimetric shape, in articulation with inherent tensions between administratively delimited space and urban occupation growth. Thirdly, we focus on some visual innovations and explorations that offer solutions for data concentration in limited spaces, as well as the figurative game spaces which were also a part of the urbanization process.

Keywords: Street map, Cartography, Urban history, Publishing market. 


\section{INTRODUCCIÓN ${ }^{1}$}

Hasta no hace muchos años, las guías y mapas callejeros en soporte de papel formaban parte del equipamiento básico del habitante promedio de cualquier gran ciudad, y más aún de los visitantes (eran, como voceaban los vendedores ambulantes en el transporte público, al igual que los peines y los bolígrafos, "indispensables para la cartera de la dama y el bolsillo del caballero"): los transeúntes precisan conocer cómo orientarse y como desplazarse, definir sus recorridos, ubicar puntos de referencia. Este artículo propone recorrer algunos aspectos de estos mapeos urbanos, que tienen un lugar ambiguo entre la producción erudita y el uso puramente instrumental para el que son habitualmente utilizados.

Pocos especialistas otorgaban a esos productos un lugar en la historia clásica de la cartografía; apenas una mención marginal o alguna nota al pie de página (Bagrow, 1966; Thrower, 1996). Pero la revisión crítica de la disciplina, el impacto de los estudios culturales y la transformación de las tecnologías de mapeo se sumaron en la formulación de nuevos interrogantes sobre los mapas en otros escenarios históricos. En efecto, con la noción de mapeo, ontológicamente más imprecisa pero más amplia que la de cartografía, se abrió el examen a las múltiples y a veces contradictorias facetas de aquello que se configuró en los últimos dos siglos como cartografía de aspiración científica a la vez que se puso el foco en los mundos sociales, técnicos y culturales de los que la cartografía formó parte (Harley, 2005; Corner, 1999; Cosgrove 1999; Kitchin y Dodge, 2007). De este modo, se hacen históricamente relevantes aspectos que una historia marcada por ideales normativos (Edney, 2019) consideraba anómalos e idiosincráticos.

Con menor intensidad, estas discusiones inciden en los estudios sobre la cartografía urbana. De manera similar a la ampliación de los objetos de estudio desde las historias del arte que se amplían a las historias de la imagen, se recupera y pone en relieve todo un cuerpo de mapas, planos e imágenes, dando relevancia a esos objetos anteriormente espurios y de escasa legitimidad como objeto de interés intelectual (Gené y Malosetti Costa, 2009). Entre ellos se destacan los planos callejeros [streetmaps]; es decir, planos en los que el énfasis visual y gráfico está puesto en ofrecer información clara de los nombres de las calles y las formas de ubicarlas. Tomados como género o variante específica (Lois, 2015), permiten encontrar otras maneras de presentar, visualizar y usar la ciudad. En ellos se advierten rasgos y características visuales que se desembarazan de las limitaciones de la topografía, y formulan soluciones para problemas que los mapas topográficos no se plantean, como la inclusión en simultáneo de nombres de calles y claves para ubicarlas, numeración de casas, distritos de numerosos tipos (policiales, parroquiales, postales, electorales, etc.), ubicación de edificios notables y comercios, direcciones útiles, líneas de transporte (ferrocarriles y tranvías). La información y las condiciones que requieren los transeúntes permanentes y temporarios promueven una amplia gama de "invenciones" gráficas, una paleta de opciones plásticas que tensa los límites de lo que se iba definiendo como cartografía en un sentido convencional y técnico a lo largo del siglo XIX.

Aunque estos mapas o planos callejeros son utilizados de manera frecuente como fuentes ilustrativas para las historias de ciudades o de manera lateral dentro de historias de los sistemas de impresión y reproducción de imágenes, no han sido objeto de una indagación sistemática desde la historia de los mapeos. Los mapas itinerarios -que se moldearon tempranamente- forman parte de aquello que se fue definiendo a lo largo del siglo XIX como cartografía temática (Palsky,1998; Verdier 2011; Morcrette, 2015), y el mapa rutero es objeto de estudio en tanto cultura impresa y cartográfica del siglo XX, de manera similar a las guías de turismo, muy relacionadas tanto con los mapas de rutas como con los planos de calles, sobre las que creció el interés desde los estudios sobre el auge del turismo moderno (González Bracco, 2017; Mendoza Vargas, 
2016). En conjunto, y en tanto "mapas de movilidad", son, como define Morcrette (2015, p.40), "operadores cognitivos de orientación".

Este panorama pone sobre la mesa cuestiones que trataremos a continuación, como las opciones adoptadas para los desafíos que plantea la presentación de un conjunto de informaciones muy dispares y las diversas soluciones gráficas y visuales que se ponen en circulación. En efecto, se trata de productos que no sólo son parte de la cultura técnica de su tiempo, sino también de una cultura impresa y visual que está en plena transformación y desarrollo durante la segunda mitad del siglo XIX, cultura que veremos en primer lugar ("Formatos editoriales y marcos de producción"). Trataremos en segundo lugar las muy diversas modalidades que se adoptan para trazar y presentar la silueta de la ciudad y su extensión, en un juego de tensiones entre el espacio delimitado administrativamente y el crecimiento de la ocupación urbana que sigue otras lógicas, y que se materializa primero en planos muy focalizados en las zonas centrales para luego superar los límites capitalinos y abarcar los inciertos ámbitos de los suburbios, en una lupa que va cambiando en contrapunto con las transformaciones metropolitanas y también editoriales ("Siluetas urbanas, del centro a las periferias"). Por último, nos interesa poner de manifiesto un conjunto de elecciones gráficas que apuntan a resolver los desafíos de la concentración de numerosos datos en espacios limitados de manera inteligible, dilema que más que una limitación actúa como desencadenante y facilitador de un conjunto de innovaciones visuales, en el que encuentran su lugar también los preciosismos técnicos, la ostentación material y los juegos ópticos ("Libertades figurativas y juegos de escala").

\section{FORMATOS EDITORIALES Y MARCOS DE PRODUCCIÓN}

En efecto ¿cómo dar a conocer la ciudad? Las narraciones para orientar a los viajeros que arriban por primera vez a una ciudad tienen una larga tradición en la cultura occidental. Se trata de advertir de los riesgos, de presentar los itinerarios más convenientes, de orientar en las transacciones comerciales y también de ofrecer parámetros para desplazarse, los recorridos favorables, los sitios de importancia, las formas de alojarse y de entretenerse; en fin, una suma de informaciones útiles para los transeúntes. Ni relatos de viajes -en los que predomina la narración y la experiencia personal-, ni derroteros, ni tratados de geografía; antes de la estabilización de la guía de turismo moderna, se trata de guías que van cambiando de formato y de estructura en el tiempo, y que a veces incluyen planos de las ciudades que describen.

Con antecedentes en España desde el siglo XVII, las "guías de forasteros" fueron un género de uso habitual en el área hispanoamericana (Cuéllar Wills, 2014), que está presente en Buenos Aires sobre todo en la segunda mitad del ochocientos. Los contenidos de este tipo de guías eran muy variados. Podían incluir almanaques (calendarios y santorales con indicación de las fechas de fiestas religiosas y civiles), información administrativa, listas de reparticiones y autoridades designadas, reglamentos de comercio y leyes de aduana, información sobre los tipos de monedas circulantes y sus formas de cambio, además de la descripción de la ciudad o sus lugares notables. En algunos casos sumaban narraciones y poemas, y muy variadas informaciones "útiles", como historias del país o un calendario agrario, además de ilustraciones. Los contenidos literarios se fueron separando de las guías, para tomar la forma de almanaques anuales de tipo literario y cultural, que además fueron incorporando imágenes, como el Almanaque Ilustradopara 1890, o el Almanaque SudAmericano para el año 1891 redactado por Casimiro Prieto y Baldés, de la imprenta El Siglo Ilustrado.

Las guías de forasteros, por su parte, a partir de la década de 1860 empezaron a incluir información comercial, no sólo general como las leyes de aduana y las tarifas, sino en forma de guía de profesiones, oficios y negocios, ordenados en forma alfabética, hasta adoptar la forma y el nombre de guía comercial o guía de comercio, que podían incluir un almanaque (Figura 1). Uno de los protagonistas de estas guías serán los "avisos comerciales", unidades destacadas que ocupan mayor espacio en la página que la línea con nombre y dirección de la lista alfabética, y que pueden combinar distintas tipografías e incluso imágenes, como fue notorio en las guías Peuser y Kraft a partir dela década de 1880 (Costa, 2018). Se trata de un formato que 
tuvo una larga vida editorial, cuyos ecos alcanzaron hasta los tomos comerciales de las guías telefónicas a lo largo del siglo XX, en las que uno o más mapas eran ingrediente indispensable.

Entre las informaciones útiles que se ofrecían a los visitantes, y más adelante también al público general, se incluía entonces un plano de la ciudad. El tipo de plano podía variar: un esquema sencillo que se integraba en una página de la guía, una página doble -también cosida en el cuerpo de la guía (Figura 2) - o una lámina suelta, de mayor tamaño y plegada. Esas láminas se entregaban junto con la guía para ser utilizadas de manera complementaria al texto, o como mapa de bolsillo, como el que se obsequiaba a los compradores de la guía Kraft de 1889, y en el que la ciudad aparecía rodeada de avisos comerciales (Figura 4). Podía entregarse también de manera totalmente independiente como gentileza a los clientes, como el de la casa Allamándola en 1887, que incluía una bella tipografía como reclame (Figura 5). Desde finales del siglo se comenzó a comercializar un nuevo producto, la guía de calles o "Guía Descriptiva" (como denominó Pablo Ludwig su edición de 1892), que se componía de dos elementos: un mapa de gran porte, plegado, que se acompañaba de un cuadernillo con el listado de nombres de calles vinculadas al plano a través de una clave alfanumérica que daba la ubicación en un sistema de filas horizontales y columnas verticales designadas con letras y números. Las combinaciones entre guía comercial y guía de calles fueron variadas, y dependían de decisiones editoriales, que orientaban su oferta de acuerdo con el mercado al que se dirigían.

Este rico universo de impresos incorporó los mapas con naturalidad y destreza. Como algunos de sus editores afirman, los mapas servían tanto a los visitantes como a la población general de una ciudad que crecía y sobrepasaba el conocimiento de los habitantes, que requerían orientaciones en los desplazamientos que realizaban de manera ordinaria o extraordinaria. En efecto, la movilidad se intensifica y se vuelve crecientemente más lejana y aleatoria a partir de los sistemas de viajes colectivos, primero en coches, más tarde en tranvías tirados por caballos y eléctricos a partir de la primera década del siglo XX (Morcrette, 2015, p. 36). A la vez, las guías comerciales permitían a los oferentes de mercancías y servicios hacerse conocer y dar su ubicación al público interesado. Este mecanismo proveía a las editoriales de una parte sustancial de los ingresos, complementaria de las ganancias por la venta de los ejemplares (que podían alcanzar varios miles en cada tirada). ${ }^{2}$ Se trataba, como dijeron los editores Mulhall (1863) en la primera edición en inglés de su Manual, Guia y Almanaque, de una "literatura efímera" destinada a ser reemplazada de manera anual al calor del movimiento comercial y demográfico, o incluso mensual cuando las guías sacaban suplementos a la guía principal (como Kraft en la década de 1890: Costa, 2018, p. 189).

Alrededor de la diversificación en las formas de los avisos comerciales, y de las maneras de presentar al usuario su ubicación mediante mapas, se reunía un conjunto importante de oficios en los que se desgranaba la división del trabajo editorial y de imprenta, como muestran Szir (2017) y varios trabajos reunidos por Ares (2018). A medida que se desarrollaban las “artes gráficas”, las empresas requerían tipógrafos, dibujantes, litógrafos, grabadores, letristas, impresores, encuadernadores: un elenco del que casi puede decirse que los cartógrafos (que en la segunda mitad del siglo XIX son, en realidad, sobre todo agrimensores o ingenieros), en tanto "autores" originales de los mapas,eran un personaje externo. De hecho, a veces ni siquiera formaban parte de las plantillas de empleados de las editoriales. En ese sentido, las habilidades necesarias para dibujar un mapa y prepararlo para la impresión mediante la litografía o el grabado no sólo eran patrimonio de los profesionales acreditados para realizar mapas, como los ingenieros o los oficiales topógrafos militares. Se trataba de pericias que manejaban también los dibujantes, delineantes o grabadores que poblaban las imprentas, como mostró Szir (2018) en el caso de la litografía que lideró César Hipólito Bacle en la década de 1830 y que publicó un mapa topográfico de la ciudad, así como mapas callejeros, cada uno respetuoso de las lógicas de su género. Sin embargo, ni Bacle ni los demás miembros de su imprenta (entre ellos su esposa Adrienne Macaire: Gluzman, G., Munilla Lacasay, L. y Szir, S., 2013) tenían una formación profesional como cartógrafos, ni eran agrimensores registrados por el Departamento Topográfico.

Es cierto, también, que muchos rasgos de esos mapas callejeros remiten a los mapas elaborados en sede estatal que también se imprimían para su venta al público, y es muy probable que las relaciones entre 
dibujantes e impresores del medio editorial y los profesionales de las oficinas públicas fueran fluidas y sostenidas. Los parecidos entre los mapas realizados por empresas privadas y los mapas oficiales ${ }^{3}$ se hicieron más notorios a partir de la formación de firmas especializadas, como la "Oficina Cartográfica” de Pablo Ludwig, activa al menos desde 1882, o de la aparición de "ingenieros geógrafos" que, como Carlos Bayer en la Editorial de Ángel Estrada, pasaban a integrar los planteles de las casas editoriales, o más tardíamente,de la firma de Máximo Randrup, que rubricaba sus productos como "editor de mapas" (Favelukes, Gómez Pintus y Novick, 2019). No es de soslayar el gradual peso de los profesionales de origen alemán en el mercado editorial y de mapas local, que traían en su formación el bagaje de la producción cartográfica de ese país que, por su parte, estaba desplazando a otras tradiciones de países europeos del podio de la producción cartográfica más precisa y elegante. Muchos de ellos reivindicaron la cartografía como su profesión. Los mapas que produjeron llevan muchas veces su marca y su nombre, en tanto los nombres de los grabadores, litógrafos e impresores aparecen a lo sumo en un borroso pie de página o son directamente ignorados.

\section{FIGURA 1}

Tapas de algunas Guías (de izquierda a derecha): El avisador, guía general de comercio y de forasteros, Solveyra (1862). Almanaque Nacional y Guia del Comercio para 1870 (...), anónimo (1869). Buenos Aires Ilustrado. Almanaque (...) para 1877, Junior y Stein (1877). Almanaque Peuser para el año de 1888, Peuser (1888).
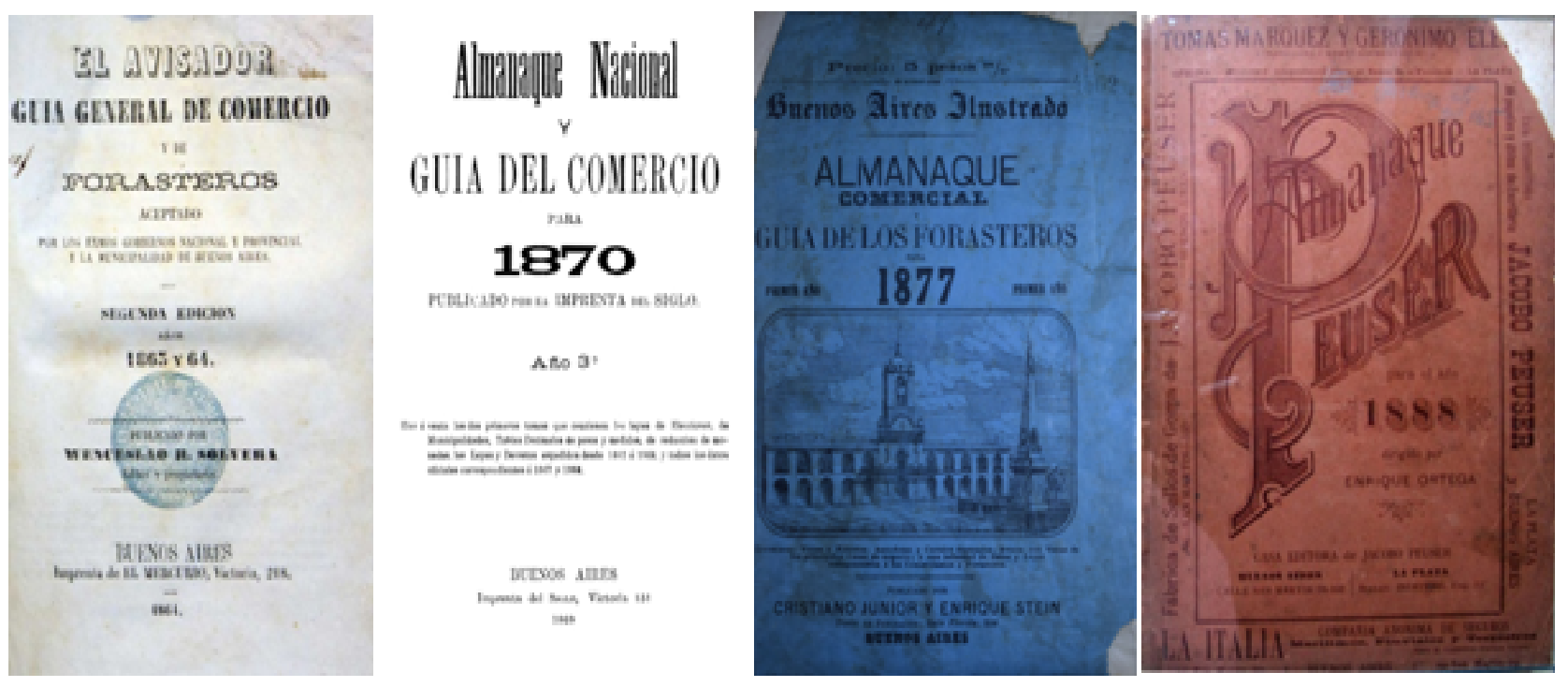
FIGURA 2

Plano de las calles de la ciudad, ajustado al tamaño de una página. En Almanaque Nacionaly Guia del Comercio para 1870 (...), encuadernado contra la portada. Dimensiones: plegado: 15.3 x $10.8 \mathrm{~cm}$; abierto: 15.30 × $21.6 \mathrm{~cm}$.

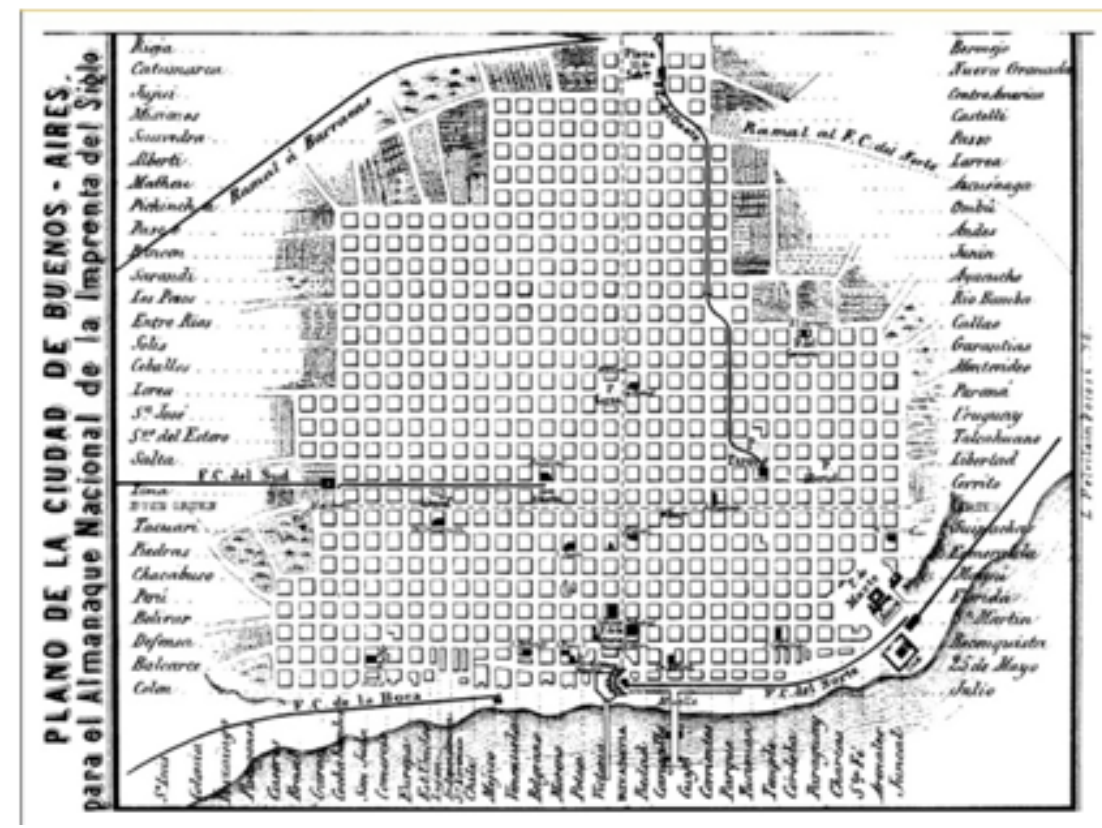

FIGURA 3

Plano de la ciudad de Buenos Aires, en Mulhall y Mulhall, 1876, p. 14. Dimensiones 18 x 11,6 cm

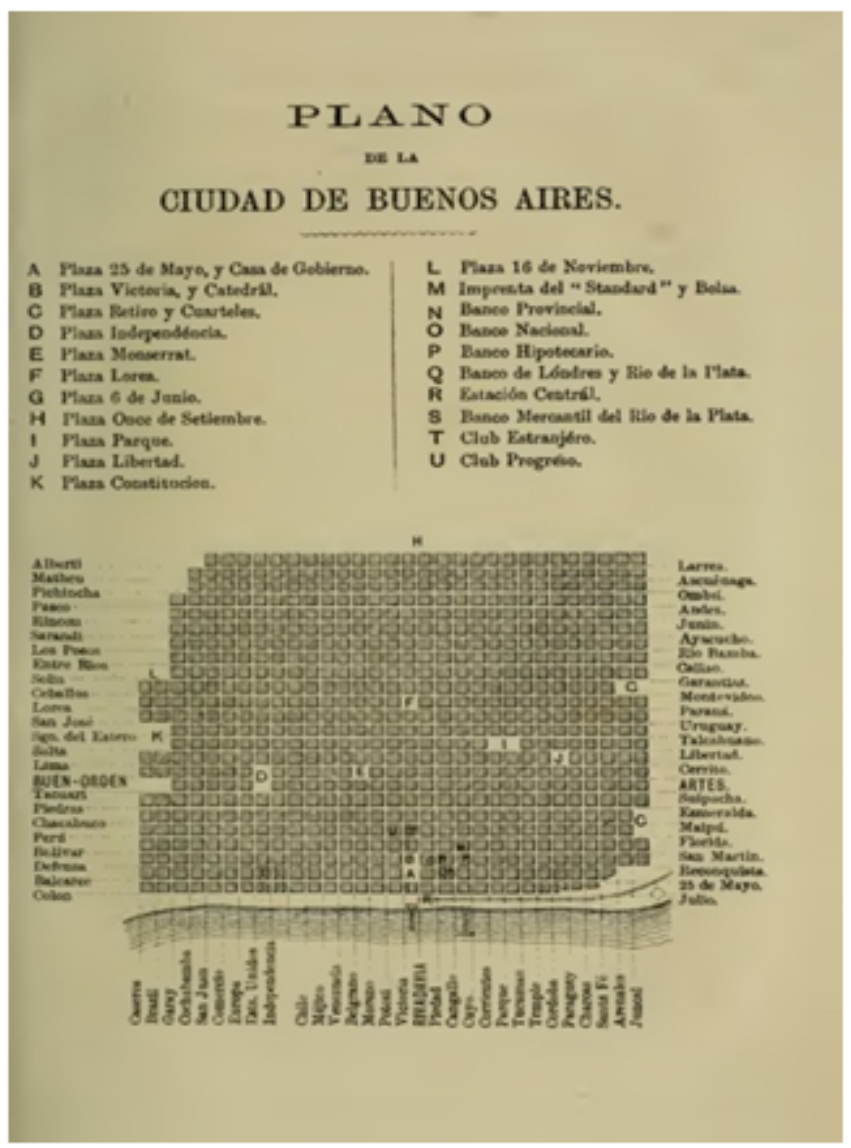


FIGURA 4

Plano de la Ciudad de Buenos Aires: obsequio a los suscritores [sic] de la Guía Kraft (aprox. 1889). Dimensiones $47 \times 61 \mathrm{~cm}$. sobre pliego $70 \times 94 \mathrm{~cm}$; escala aproximada 1:19.500 https:// catalogo.bn.gov.ar $/ \mathrm{F} /$ ?func $=$ direct\&doc_number $=001301427 \&$ local_base $=$ GENER).

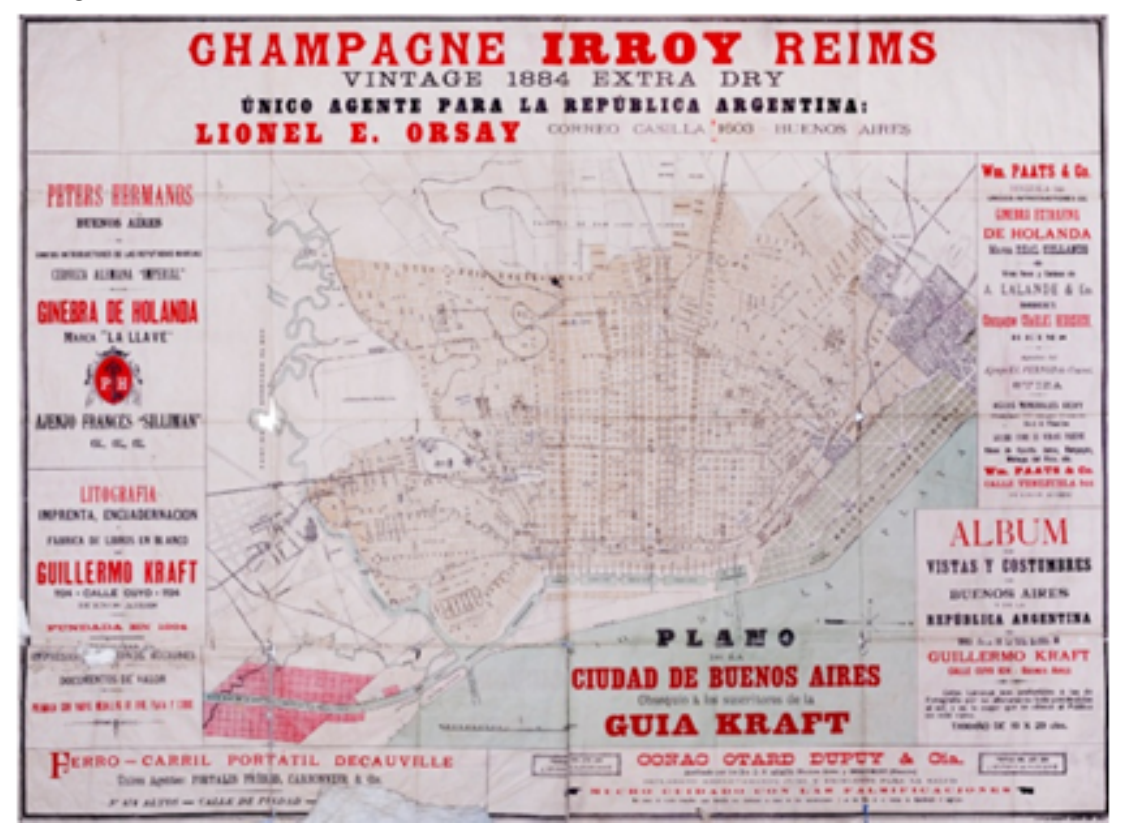

\section{FIGURA 5}

Plano de la Ciudad de Buenos Aires: obsequio a los suscritores[sic] de la Guía Kraft (aprox. 1889).

Dimensiones $47 \times 61 \mathrm{~cm}$. sobre pliego $70 \times 94 \mathrm{~cm}$; escala aproximada 1:30.000. https:// catalogo.bn.gov.ar/F/?func=direct\&doc_number=001301443\&local_base=GENER).

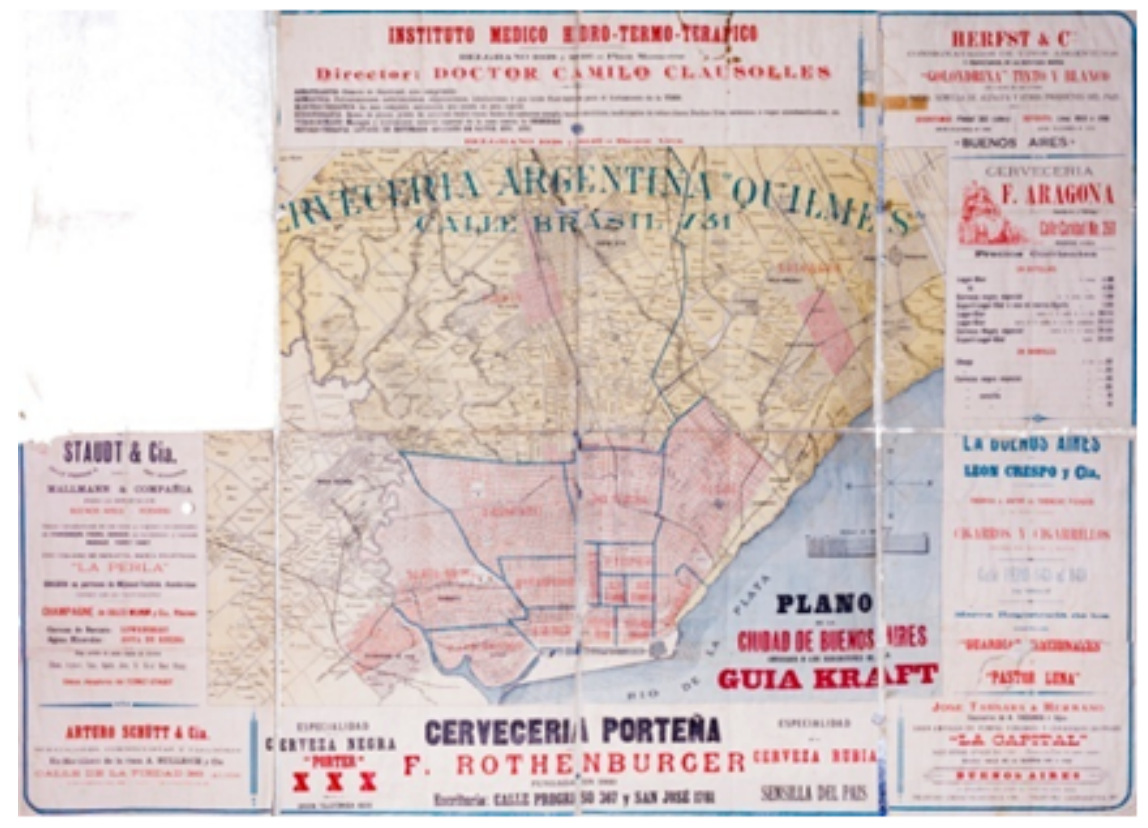




\section{FIGURA 6}

Ciudad de Buenos-Aires y Distrito Federal (1900) (publicado por Pablo Ludwig, cartógrafo, según los datos oficiales y observaciones propias). Dimensiones $72 \times 95 \mathrm{~cm}$, escala 1:35000. Con clave cromática. https://catalogo.bn.gov.ar/F/?func $=$ direct\&doc_number $=001285976 \&$ local_base $=$ GENER

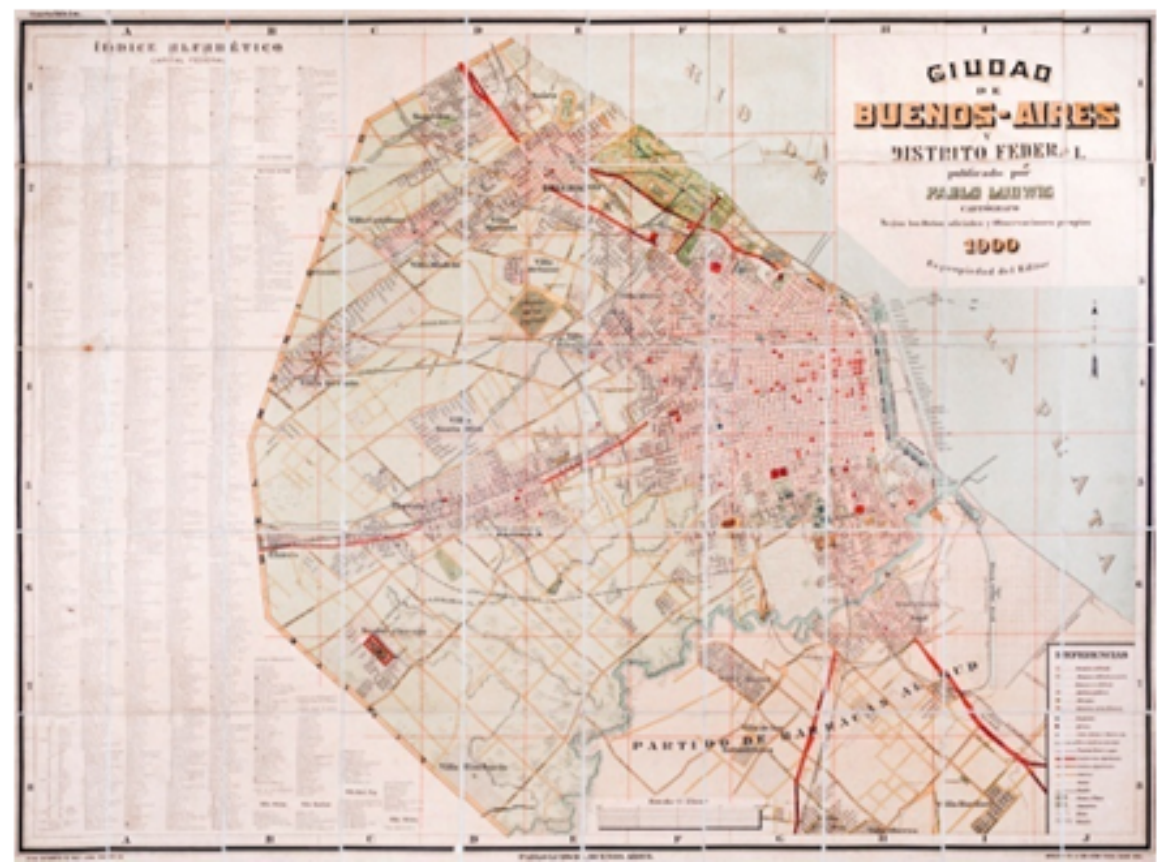

FIGURA 7

Plano de la Ciudad de Buenos Aires y sus alrededores, ejecutado por los Talleres de Jacobo Peuser(1912). Dimensiones 80 x $87 \mathrm{~cm}$, escala 1:25.000. https:// catalogo.bn.gov.ar $/ F /$ ?func $=$ direct\&doc_number $=001060240 \&$ local_base $=$ GENER

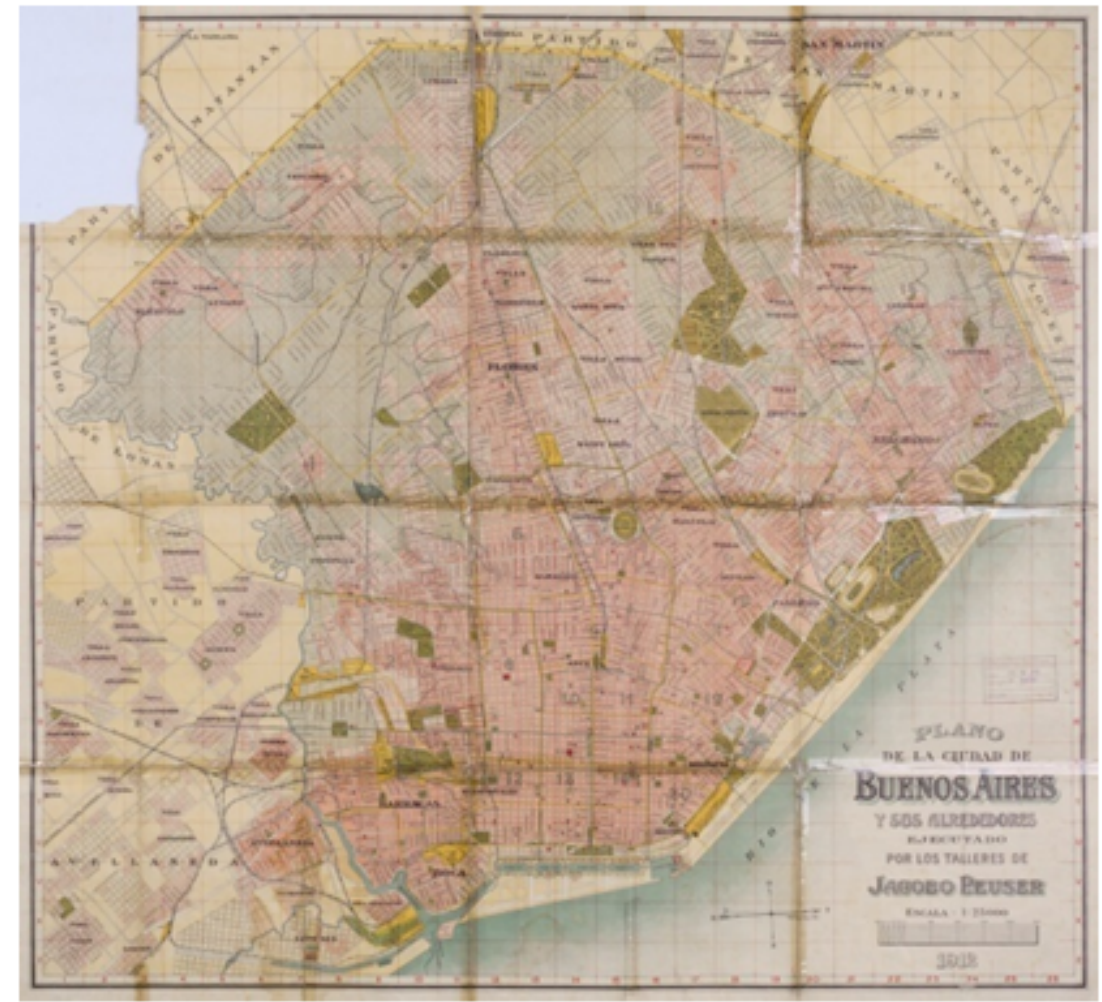


FIGURA 8

Plano de la Ciudad de Buenos Aires y Avellaneda, Oficina Cartográfica de Baz y Cabral (1933). Litografía, dimensiones 54 x $67 \mathrm{~cm}$, escala 1:35.000. Con clave cromática.https:// catalogo.bn.gov.ar $/ F /$ func $=$ direct\&doc_number $=000093002 \&$ local_base $=$ GENER.

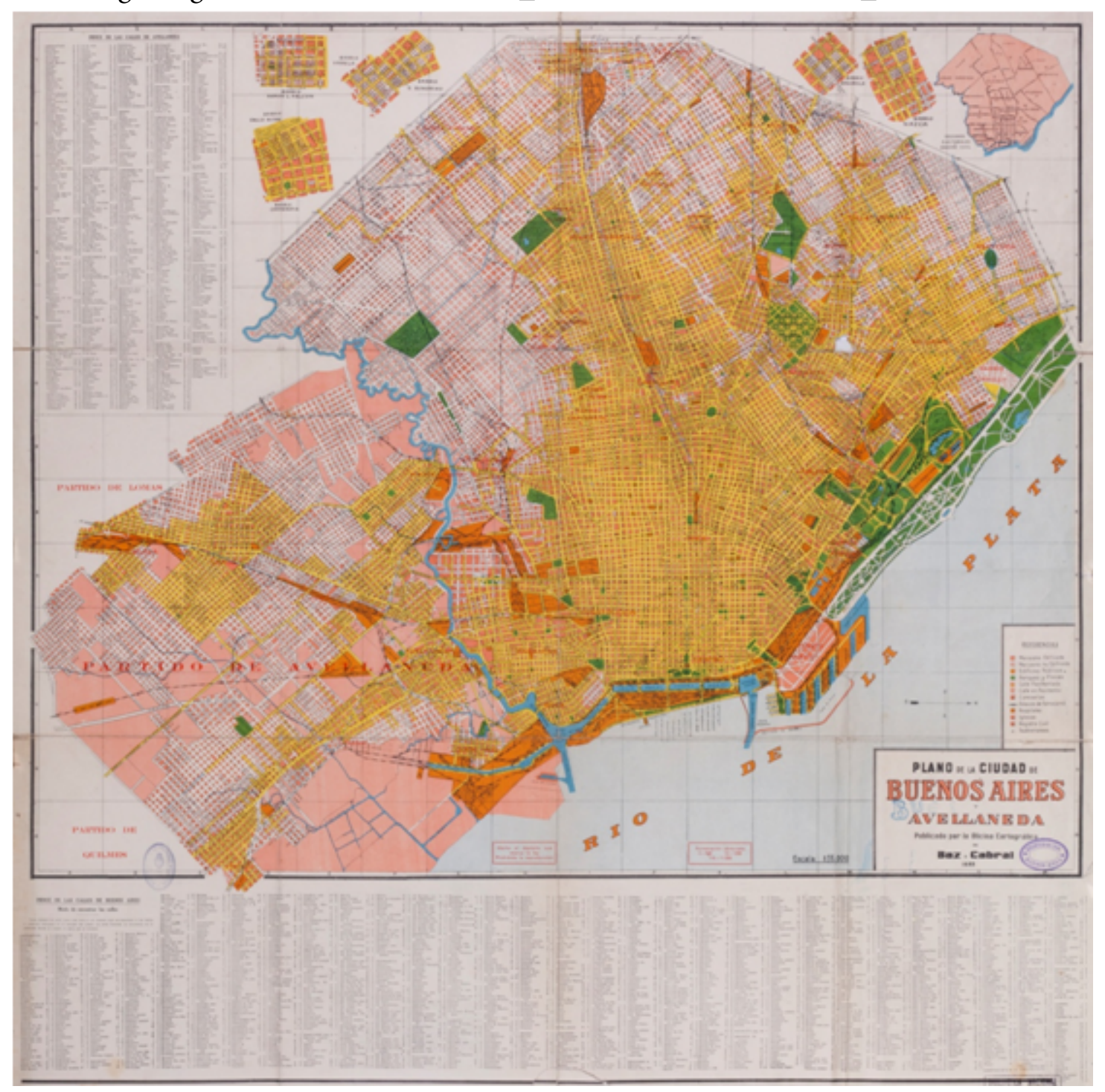




\section{FIGURA 9}

Nomenclatura de las calles de Buenos-Aires, en Coni, 1868, p. 16. Dimensiones 15 x $9.5 \mathrm{~cm}$.

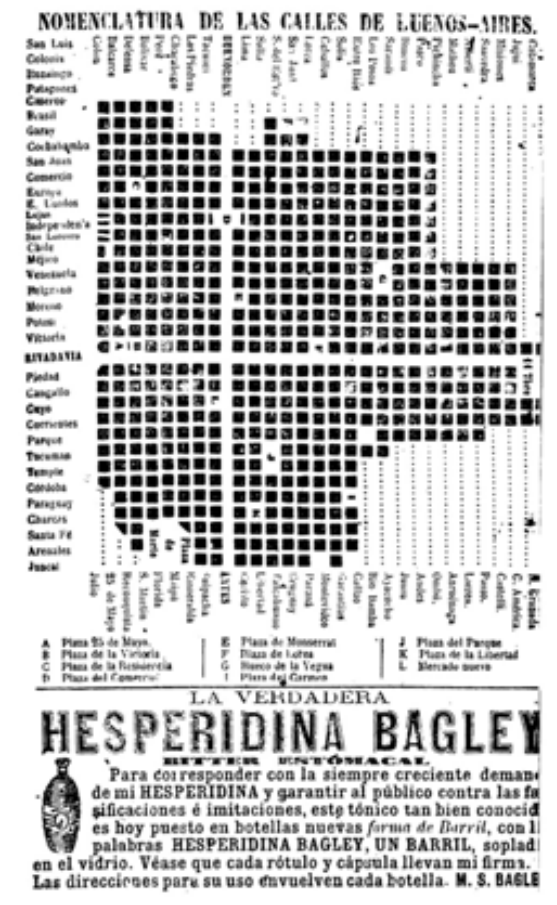

FIGURA 10

Plan of the city of Buenos Ayres, en Mulhall 1892, p. 687. Dimensiones 18 x 11,6 cm.

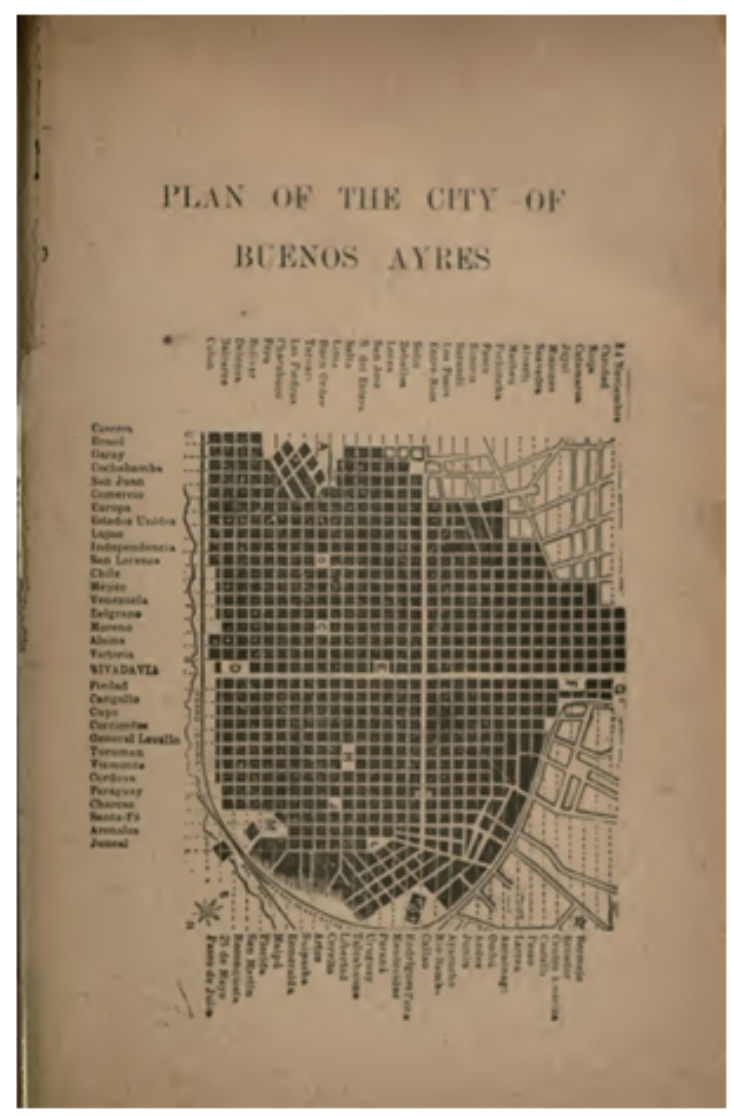


FIGURA 11

Plano de la ciudad de Buenos Ayres, Pierre Chameau (1887). Dimensiones 25 x $40 \mathrm{~cm}$. Sin escala. Bibliothèque Nationale de France, GED-569. http://catalogue.bnf.fr/ark:/12148/cb40723444j

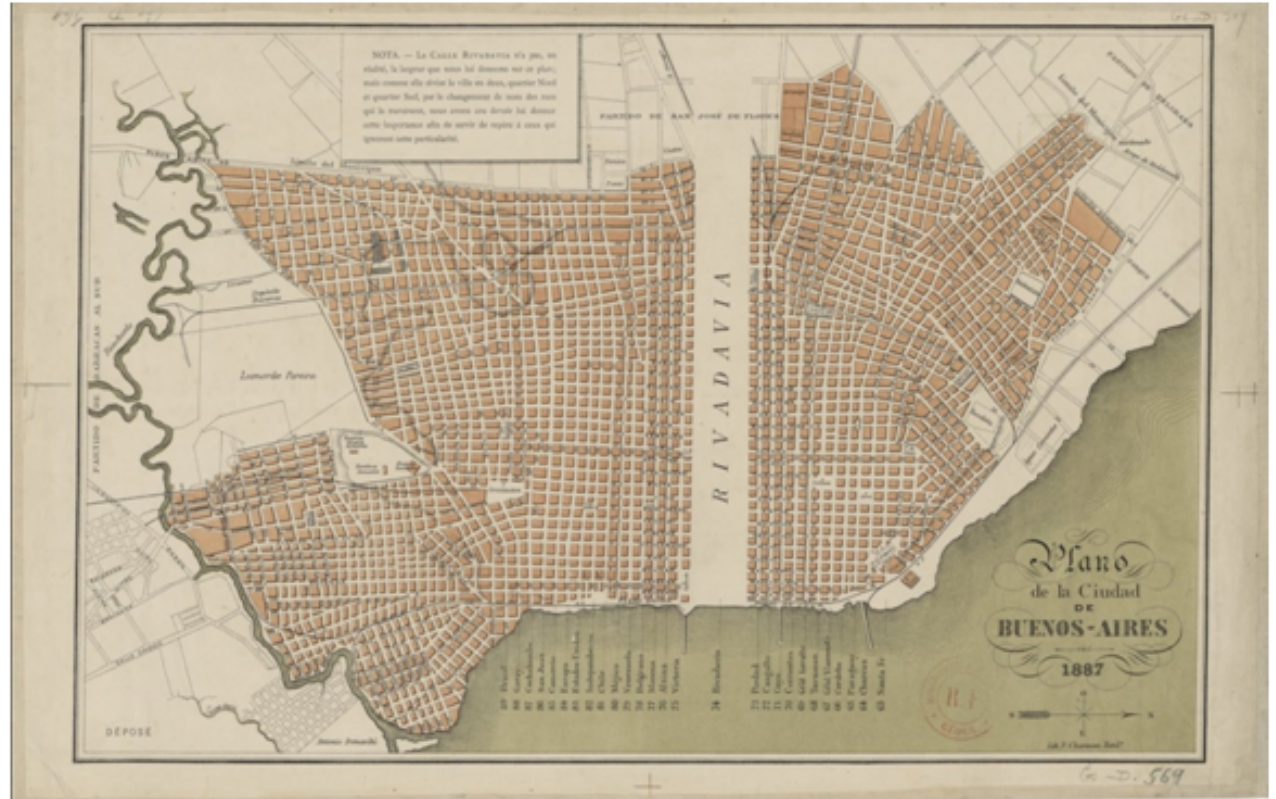

FIGURA 12

Novísimo plano moderno de Buenos Aires, José Ritter (1905). Dimensiones 69 x 87 cm, escala 1:31.500. https://cartotecadigital.icgc.cat/digital/collection/america/id/806/rec/4.

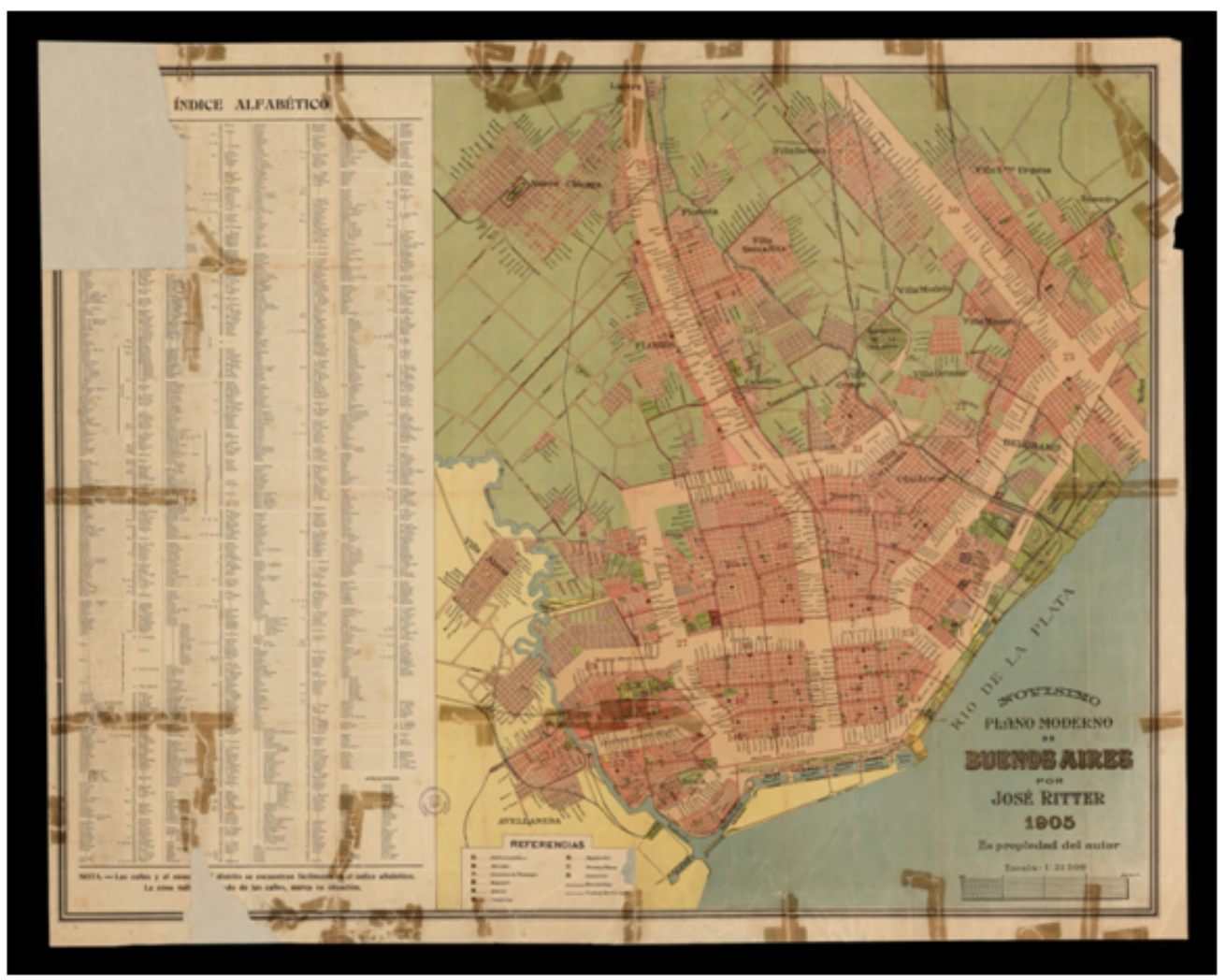


FIGURA 13

[Autor anónimo] 1895. Dimensiones 107 x 107 cm, sin escala. Museo Mitre, ID: 8036-00272.

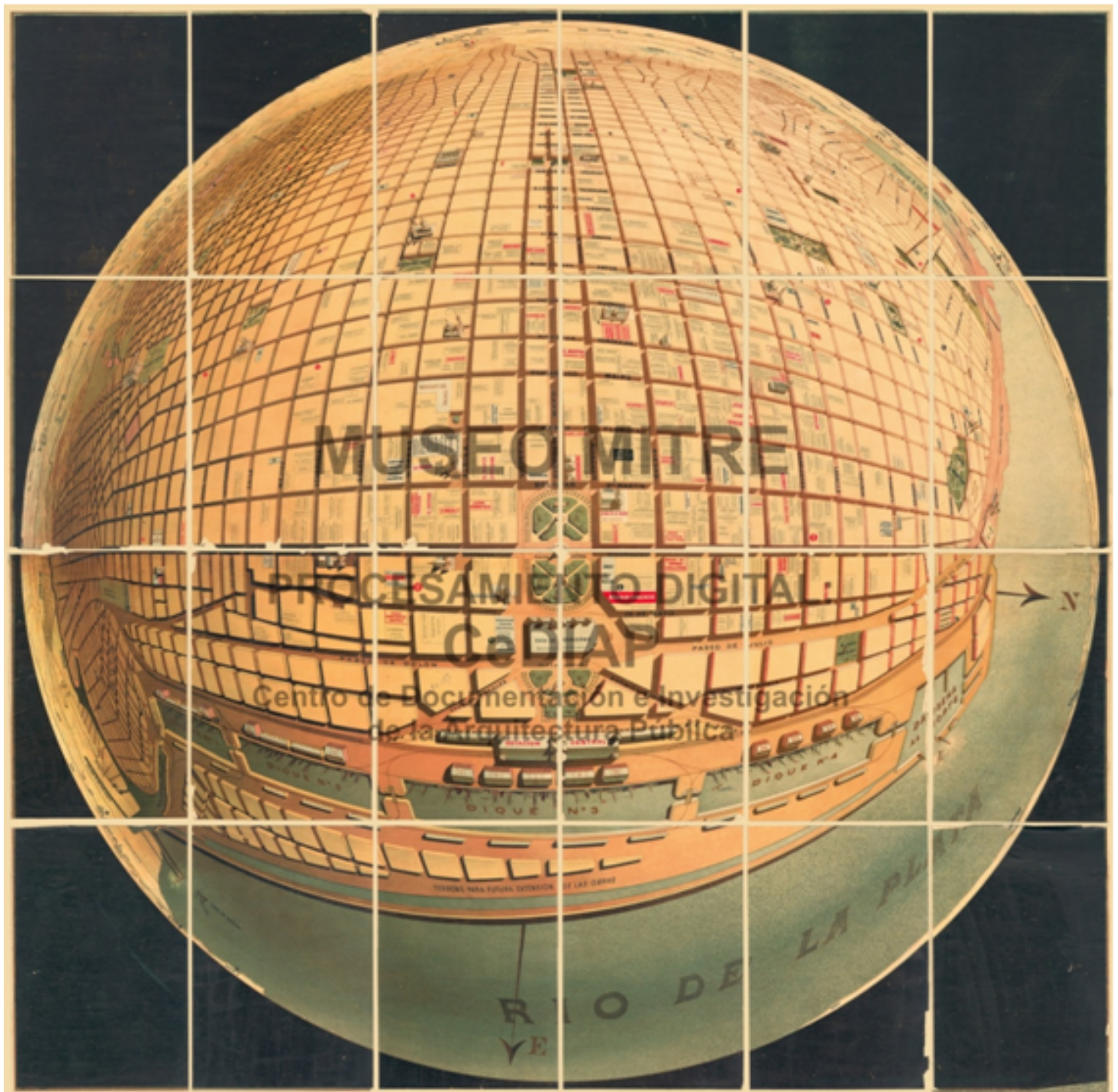

\section{Siluetas urbanas, DEL CENTRO a las PERIFERIAS}

Los planos callejeros plantean una pregunta recurrente: ¿hasta dónde llega la ciudad? (Novick y Favelukes, 2019). En el caso de las guías y planos callejeros, la cuestión admite múltiples respuestas. En efecto, la ciudad puede ser ese sector, en general céntrico, donde la edificación es compacta y las calles son continuas. Si el criterio es dar indicaciones para ubicarse en ese sector compactamente edificado, los suburbios, los arrabales se vuelven irrelevantes, pues a nadie le será necesario desplazarse a esas zonas donde se desparraman algunas casas y cobertizos, obrajes, corrales y terrenos baldíos. Por cierto, son zonas que para las autoridades son extremadamente importantes, y reciben toda la atención de los departamentos técnicos encargados de ofrecer cartografías confiables para la definición de secciones administrativas o judiciales, o para el trazado de calles a partir de la subdivisión de los grandes terrenos antes rurales. Esos sectores raramente reciben el interés de los mapas callejeros y las guías con las que se vinculan.

Tal condición define que las siluetas de las plantas urbanas que ofrecen este tipo de planos resulten a veces un recorte que elimina áreas significativas, comparados con los planos oficiales como el de 1867. En los 
pequeños mapas dentro de las guías, comprimidos al tamaño de una página o incluso menos, se va definiendo una forma urbana muy abstracta que se ofrece a la vista sobre el fondo completamente neutro de la hoja de papel blanco. En ellos, la ciudad se reduce a un damero de manzanas pintadas de negro pleno, separadas por calles rectas blancas, todo rodeado por una corona de nombres de las calles, que ocupan el lugar de la periferia que se elimina y flotan sobre el espacio del río. Un ejemplo de esta variante se encuentra en el Manual de las Repúblicas del Plata de los hermanos Mulhall, publicado en 1876. El libro, de más de 400 páginas, incluye un mapa de Argentina, Uruguay y Paraguay, un plano de Montevideo (de hoja doble) y un plano o más bien esquema de Buenos Aires (Figura 3).

El plano que incluye la guía de los Mulhall tiene muchos puntos en común con otros planos de calles que circulaban en años previos, como el que publicó César Hipólito Bacle en 1840 o el de Nicolás Grondona de 1856, ambos comercializados como láminas sueltas (Taullard, 1940). De tamaño reducido (ocupa menos de la mitad de una página de la guía, cuya altura es de $20 \mathrm{~cm}$ ) y con una factura aún más austera que sus antecesores, este plano minimalista presenta una escueta cantidad de información: la planta de la parte central de la ciudad, con su tejido de calles y manzanas. La silueta de las manzanas es homogénea y continua, y apenas se insinúa una ruptura con la extensión isomorfa de la ciudad en el gradiente de la periferia sur, cuyo recorte no sigue una línea continua; esta es la única sugerencia que remite a la silueta de la ciudad construida en esos años, que era más amplia y bastante más irregular y discontinua, como muestra el plano topográfico de 1867 (Taullard, 1940). Una clave alfabética, que remite a una lista en la mitad superior de la página, indica la presencia de plazas y algunos puntos considerados notables: los principales bancos, la estación central de ferrocarril, los dos clubes existentes (Club Extranjero y Club del Progreso) y la imprenta The Standard, propiedad de los Mulhall y donde se publicaban los manuales y guías, además del periódico del mismo nombre (desde 1861). Rodeando la traza se colocan los nombres de las calles, que cambiaban de denominación en dos calles principales, en el sentido norte-sur y el sentido este-oeste. Esta suerte de ejes se indica mediante una tipografía en mayúsculas: la calle Rivadavia, las de Buen Orden y Artes (hoy Bernardo de Irigoyen y Carlos Pellegrini).

El problema de hasta dónde dibujar el territorio dependía tanto del tamaño de la hoja disponible para el mapa como de la extensión que se resolviera incluir, cuestión que tampoco era independiente de la superficie misma del área urbanizada. Ajustar la silueta a los límites administrativos, en cambio, no era indispensable. En efecto, al contrario que los planos que se dibujaban desde las oficinas estatales, para los que los límites de la ciudad definían los límites de la jurisdicción administrativa (por lo tanto, electoral, sanitaria, policial, de alumbrado y pavimentos, entre muchas otras facetas), los planos callejeros se movían con mayor libertad y podían privilegiar otros criterios. A veces reducían el encuadre a la zona central consolidada y soslayaban las zonas algo alejadas pero que estaban dentro de los límites de la ciudad (como el caso del plano del Almanaque de Coni de 1868 -Figura 9-, el de la guía de Mulhall de 1876 -Figura 3- e incluso el de la de 1892 -Figura 10-, o los de la guía Kraft de 1889 -Figura 4-); otras veces se abrían más allá de esos límites. Estos aumentos de la superficie dibujada se observan sobre todo a partir de comienzos del novecientos, cuando el crecimiento empieza a establecer una continuidad con los pueblos vecinos (como ya se anuncia en los planos de la Oficina Cartográfica de Pablo Ludwig en 1900, por cierto, impreso en la Editorial de Peuser -Figura 6-). El crecimiento más allá del límite capitalino impulsa una extensión cada vez mayor del área mapeada, con listas de calles cada vez más voluminosas, una escala cada vez más grande y un tamaño de papel que amenaza la factibilidad de su uso. Justamente para conservar un tamaño portable y una escala legible, la cuestión se termina resolviendo a veces con el sistema de la guía de calles que acompaña el mapa, como vimos más arriba.

Para ejemplificar, vale revisar dos planos de la guía Kraft realizados con un año de diferencia (Figuras 4 y 5). En el primero, publicado en 1889 dos años después de la federalización de la capital y de su ampliación hasta sus límites actuales, la imagen destaca, mediante un coloreado de fondo, la superficie definida por los límites que habían estado vigentes desde 1867, la que se rodea de un fondo blanco con algunas indicaciones de caminos y escasa toponimia. El plano publicado por la misma firma editora un año más tarde se amplía y 
usa una escala algo menor para incorporar la casi totalidad del nuevo territorio federal, incluidos los antiguos pueblos de Flores y de Belgrano. El uso de colores permite diferenciar sectores dentro del plano, utilizando las ya antiguas convenciones del dibujo ingenieril: el carmín para las áreas edificadas y el amarillo para las áreas no edificadas. Así, la huella de los límites previos sigue visible mediante un tono rosado que indica las zonas amanzanadas existentes (y subdivisiones proyectadas), en tanto las zonas adyacentes al área del antiguo municipio se pintan de dos tonos de amarillo: el más fuerte para las tierras que ahora integran la Capital Federal, donde se presentan no sólo los terrenos todavía rurales, con los nombres de sus propietarios, sino también algunos proyectos de subdivisiones y trazados nuevos, y un amarillo más suave para los terrenos externos a la Capital. Esbozando el crecimiento que va a terminar conectando los pueblos y poblados antes separados, los pueblos vecinos al Riachuelo se colorean también en tono rosado, de modo que las dos Barracas -al sur y al norte- se conectan visualmente a ambos lados de la frontera fluvial. En un momento en el que es muy reciente la definición del nuevo límite de la ciudad y su extenso territorio, el uso del color está puesto al servicio de los viejos códigos topográficos, y la silueta urbanizada todavía no adopta la forma del mapa logotipo de la Capital Federal que se fue construyendo en las décadas posteriores.

$\mathrm{Al}$ mismo tiempo que en los círculos profesionales y técnicos se comenzaba a advertir sobre una expansión poco controlada con el nombre de Gran Buenos Aires, cuya forma se pensaba radialmente a partir del centro, los planos callejeros hacían y deshacían territorios disímiles, como el plano de Peuser de 1912 (Figura 7), que presenta numerosos sectores amanzanados (efectivos o proyectados) en las afueras (Gómez Pintus, 2019), o el mapa de la Oficina Cartográfica de Baz y Cabral de 1933, que opta por unificar en una misma figura la Capital con el partido de Avellaneda (que incluía el actual partido de Lanús (Figura 8).

Así, en tanto cada jurisdicción administrativa marca con contundencia los límites del territorio municipal que le compete, la ocupación y edificación se extiende según otras lógicas (continuidad de las infraestructuras, calidad del suelo, relación con la estructura de caminos, oportunidades y ritmos del fraccionamiento de lotes rurales, impulso económico y formas de financiamiento, así como -crucial para nuestro objeto de estudioel desarrollo y recorrido de los medios de transporte público). Ese crecimiento, que supera los límites entre administraciones y territorios locales, es difícil de observar para las atomizadas oficinas municipales y para la siempre presente tensión entre las jurisdicciones nacional y municipal vigentes en la Capital, así como las competencias municipales y provinciales en los partidos vecinos. La dinámica de la expansión, sin embargo, está claramente presente en los planos callejeros que circulan entre el público local y visitante, entre los avecindados que transitan de un lugar a otro la ciudad y los inversores que buscan oportunidades de negocios, en una magnitud tal que terminó por hacer imposible que se contuviera la totalidad de la información espacial de la ciudad metropolitana en una sola hoja de papel plegable y portátil. La solución a partir de la década de 1950 estará en las guías que subdividían la capital en hojas numeradas, y que agregaban una hoja para cada partido del Gran Buenos Aires, como la Guía Filcar (Gómez Pintus, 2019).

\section{LIBERTADES FIGURATIVAS Y JUEGOS DE ESCALAS}

Para los historiadores de la ciudad y los historiadores de la cartografía que buscan en los mapas esa ciudad de la que son reflejo o representación, así como su progresiva mejora en la calidad técnica, los mapas firmados por Pablo de Ludwig figuran seguramente entre los más interesantes y característicos de unas prácticas técnicas que se refinaban a finales del siglo XIX y en las que los mapas de las oficinas estatales eran un insumo central y una garantía de calidad y exactitud. Sin embargo, reservamos para este punto un conjunto de planos en los que la "fidelidad" en términos planimétricos y dimensionales quedó rezagada ante otras decisiones gráficas. Y si recién vimos algunas variaciones en la superficie que comprendían los planos, aquí interesa analizar una diversidad de licencias y libertades figurativas que desafían la estabilidad de la construcción topográfica, y presentan un ejercicio de elocuencia visual que raya en el virtuosismo, al poner en juego licencias cartográficas como deformaciones, juegos de escala y fantasías perspectívicas. 
Una de estas transformaciones se relaciona con el desafío de incluir todos los nombres de todas las calles de manera legible, aun en planos de menor tamaño. Aunque la tradición indica que Buenos Aires tiene un trazado en forma de damero, en los hechos se trata de un tejido con geometrías más irregulares. Asimismo, a medida que la ciudad se extiende más allá de la traza fundacional, las calles reciben nuevos nombres, aun cuando tienen continuidad espacial. La delimitación de esos nombres se define mediante calles que actúan como divisorias de nomenclatura y numeración. Las divisorias más antiguas se localizaban a lo largo de la calle Rivadavia, y de la calle Artes (al norte de Rivadavia) y Buen Orden (al sur), hoy llamadas Carlos Pellegrini y Bernardo de Irigoyen. Esta divisoria se trasladó en 1887 a la calle Cuyo (hoy Río de Janeiro, al norte de Rivadavia) y Avenida La Plata (al sur, hoy del mismo nombre). Pero muchas de esas divisorias de nombres que disponía la normativa urbanística (que fueron aumentando en cantidad) se establecían en calles cuya anchura no era mayor que aquellas cuyos nombres cambiaban a uno y otro lado. ¿Cómo destacarlas visualmente? Este fue un terreno de experimentación, creación de soluciones e introducción de libertades figurativas y licencias cartográficas. Un ejemplo temprano aparece en un plano mínimo en el Almanaque de la imprenta de Pablo Coni de 1868 (Figura 9), y también en un plano similar de la guía de Mulhall del año $1892^{4}$ (Figura 10).

En ambos casos se observa un aumento del ancho de las calles divisorias. Coni aumenta el ancho de Rivadavia (que medía 11 varas hasta Callao) y de Artes/Buen Orden (que también medía 11 varas), y Mulhall también aumenta Rivadavia. Los ejes ensanchados de estos planos soslayan esas particularidades y optan por enfatizar una suerte de esquema en cardo y decumano (a imagen de las ciudades antiguas fundadas por los romanos, cuyo tejido cuadricular con ejes ortogonales se mencionabacomo antecedente de los trazados de las ciudades hispanoamericanas).

Esta libertad figurativa de representar las calles sin respetar la proporción de tamaño con su referente pone en tensión el concepto típico de escala en la cartografía, que queda subordinada al objetivo de visibilizar el uso de la ciudad. Estos mapas sacrifican la proporción lineal de la escala por una que prioriza otro tipo de relaciones espaciales, en este caso la calle como divisora toponímica que, podría decirse, crea una topografía alternativa. En efecto, la ciudad que en esos años los críticos urbanos veían como una repetición interminable de la manzana cuadrada con calles angostas (una herencia colonial que se proponía abandonar) se convertía en estos esquemas en una ciudad dignificada por dos ejes ortogonales ficticios que, podría decirse, preanuncian a la vez que promueven imaginariamente las avenidas y bulevares que más tarde modernizaron la ciudad.

Si bien los planos impresos por cromolitografía (Ares, 2018; Costa, 2018) permitían destacar esa información con colores -solución que adoptó, entre otros, el plano de Peuser de 1912 al resaltar las divisorias con color amarillo, sin alteraciones de proporcionalidad (Figura 7)-, el recurso del ensanche visual no se abandonó y recibió nuevas variaciones. Un primer ejemplo se observa en un plano coloreado de 1887 litografiado por P. Chameau en Burdeos, Francia, posiblemente para su comercialización en ese país (Figura 11). La ciudad retratada se ciñe al límite vigente desde 1867 , y las manzanas se colorean de manera uniforme en un tono rosado sobre un fondo blanco que corresponde a las calles y a las tierras que rodean la trama. La información principal son los nombres de las calles (también numeradas, siguiendo una efímera numeración de calles que había propuesto la municipalidad en 1882). ${ }^{5}$ El rasgo sobresaliente es el inusitado ancho otorgado a la calle Rivadavia (recordemos, de 11 varas de ancho, como todas las demás calles de la traza hispánica, y de 20 varas hacia el oeste de Callao-Entre Ríos), que se refuerza con el nombre impreso con letra de gran tamaño. El autor del plano no quiso dejar sin justificación su gesto gráfico, para lo cual incluyó un recuadro escrito en francés en el borde superior izquierdo en el que explica:

NOTA: La CALLE RIVADAVIA no tiene, en realidad, el ancho que le damos en este plano; pero como ella divide la ciudad en dos, barrio Norte y barrio Sud, para el cambio del nombre de las calles que la atraviesan hemos creído deber darle esta importancia para servir de orientación a aquellos que ignoran esta particularidad (Traducción propia)

El recurso del ensanche de las vías donde cambia la nomenclatura aparece llevado al paroxismo en el Novísimo plano moderno de Buenos Aires firmado por José Ritter en 1905 (Figura 12). Vivamente coloreado, 
presenta gran parte de la ciudad y una pequeña porción del partido de Avellaneda al sur. El recorte adoptado parece estar vinculado a la extensión del tejido amanzanado a lo largo de los caminos principales, pero no alcanza a los límites de la Capital. El costado izquierdo está dedicado a un detallado listado de calles referido a la traza mediante una clave alfanumérica. El cambio de escala alcanza en este caso a todas las vías en las que se realizaba el cambio de nombre. Las libertades que se tomó el dibujante no están exentas de una intensa laboriosidad. En efecto, el autor ha debido utilizar dos escalas en el mismo dibujo. Una escala para los anchos de aquellas calles que marcan el cambio de nombre y numeración, y otra escala para la trama de manzanas y calles comunes. El aumento del ancho de las divisorias le sirvió al autor para incorporar los nombres a uno y otro lado, sin interferir con el resto del dibujo. El logro del dibujante está en haber conseguido aumentar los anchos de las calles divisorias y a la vez mantener las relaciones proporcionales del resto de la trama, que queda configurada en una serie de "islas" internamente consistentes, separadas por el recurso visual de esa suerte de "pasillos" coloreados de amarillo donde los nombres encuentran un lugar cómodo y se destacan con claridad.

Es interesante cerrar este recorrido por el rico territorio de las manipulaciones gráficas de los mapas de la ciudad con una pieza que muestra un llamativo despliegue técnico y visual. Se trata de un plano de autor anónimo, de gran formato y de 1895 , que contiene una importante serie de alardes visuales, perspectívicos y gráficos (Figura 13). En este caso la libertad figurativa no pasa por el manejo expresivo de las escalas, sino porla propia construcción de una imagen a la vez planimétrica y volumétrica. El conjunto remite a varios juegos figurativos del arte visual, desde la imagen en lente de pescado que se exploró en la pintura desde el siglo XVI hasta la proyección esférica, recursos que combina con la perspectiva curvilínea a la vez que utiliza la axonometría o perspectiva paralela para retratar los edificios principales.

La perspectiva curvilínea se formuló durante el siglo XIX (su método se empezó a definir en 1853 y para finales del siglo ya se incluía en manuales de dibujo técnico y geometría: Ware, 1882). Se utilizaba sobre todo para resolver los dilemas de la perspectiva cuando abarcaba ángulos superiores a los $30^{\circ}$, punto en el que las líneas rectas del centro del campo visual se empiezan a tornar curvas. Este método podía incluir el uso de hasta seis puntos de fuga y era de compleja realización. En este caso nos encontramos ante un tour de force gráfico que usa la deformación proporcional del método curvilíneo, ya no para ofrecer la visión de un panorama desde un punto de vista cercano al suelo, sino como forma de abarcar el conjunto de la ciudad (la de los límites de 1867) desde un punto de vista aéreo en el que el punto de vista se coloca sobre una vertical elevada sobre el área central de aquella. Pero en vez de adoptar una proyección horizontal o visión cenital, adopta esta perspectiva curva que permite conservar el efecto o la ilusión delcampo visual del ojo humano.

Por una parte, este juego contribuye a resaltar el área central, donde el mayor tamaño de manzanas, calles y edificios permite incluir una abundante cantidad de informaciones útiles típicas de los mapas callejeros: nombre de calles, identificación de edificios y lugares importantes (con sus volumetrías); incluso despliega los nombres de numerosos comercios, firmas profesionales, bancos y empresas indicando su ubicación mediante el dibujo de las parcelas que ocupan. Todo esto habla tanto de las abundantes fuentes públicas y privadas utilizadas, como de la habilidad del equipo de autores de este plano/cuadro, que posiblemente estuvo acompañado de una guía impresa. Por otra parte, la perspectiva curva hace reducir las proporciones del dibujo hacia la periferia de la ciudad, que se desvanece en una atmósfera de la misma vaguedad que experimentaría la mirada. En suma, una obra gráfica de lujo y un mapa que despliega una ciudad que en su curvatura sugiere un mundo sin límites.

\section{NotAS DE CIERRE}

Este trabajo quiso presentar mediante algunos planos callejeros de Buenos Aires una etapa en la que, al mismo tiempo que en el ámbito científico-técnico y en las instituciones estatales se definía una manera legítima de mapear la ciudad, estaban realizándose otros mapeos con similitudes, pero también diferencias respecto de los restrictivos parámetros de la cartografía oficial. Estos mapeos son una llave para poner en consideración un universo amplio de productores de mapas (grabadores, letristas, ilustradores, ingenieros) y 
sus lógicas de elaboración, en las que la autoría, una vez más, se vuelve múltiple y colectiva. Y en última instancia, examinar estas piezas gráficas contribuye, también, a interrogar cuestiones que están en juego en los procesos de modernización de la ciudad y que marcaron la producción de gráficos e imágenes en respuesta a demandas que no formaban parte de las preocupaciones de los organismos oficiales. Más que una dicotomía entre ambas esferas de producción de mapas o un cuestionamiento de las normas del dibujo topográfico, este repaso permite poner en consideración las licencias y soluciones que se adoptaron en pos de la expresividad y la utilidad. En este sentido, más que mapeos alternativos entre sí, se trata de productos complementarios con vasos comunicantes y que en conjunto forman parte de un universo técnico, visual y cognitivo.

En efecto, estos planos callejeros formularon, a través de la selección de elementos a mostrar y de diversos recursos plásticos, una ciudad análoga, que fue un insumo para la experiencia del público que se construye y reconstruye sobre la base de estos impresos efímeros, destinados a usarse y gastarse, romperse y reemplazarse en el sucederse de las ediciones siempre más actualizadas que los vuelven rápidamente obsoletos.

Los planos callejeros promueven así la formación de imágenes mentales que retratan un espacio urbano distinto de aquel que está edificado y que nadie puede ver en su totalidad. La apreciación de las distancias varía no sólo de acuerdo con las dimensiones materiales a recorrer, sino también con el conocimiento previo de los lugares, con los modos de organizar el desplazamiento. La propia forma de la ciudad se vuelve maleable y admite reorganizaciones visuales y proporcionales que redefinen los itinerarios, pero también las imágenes y las simbolizaciones de los transeúntes, la manifestación visual de una espacialidad no material y no dicha, pero no por ello menos importante. Y hasta cierto punto, puede pensarse que la instalación de la idea de la cuadrícula urbana como dispositivo de extensión infinita y ubicua que terminó por ser parte del patrimonio simbólico de los porteños les debe mucho a estos planos callejeros que construyeron a la vez que domesticaron la expansión, que volvieron manejable y aprehensible la aparentemente imparable extensión de la trama.

Así, el espacio isótropo del mapa topográfico muta y se transforma en una suerte de ensamblaje de espacialidades antagónicas y escalas disímiles. En ellas, la forma de la ciudad que se ofrece a la mirada contiene dimensiones y puntos de vista que, aunque controvertidos en términos lógicos y geométricos, convergen y resultan eficaces como auxiliares del desplazamiento y las operaciones cognitivas que requiere el conocimiento práctico del espacio urbano. Recogiendo algunos de los hilos que fuimos tejiendo, podemos retomar la idea del mapa itinerario (y del mapa callejero) como dispositivo cognitivo de orientación que plantea Morcrette o, como quisiéramos proponer, como "visualizaciones para el desplazamiento". De alguna manera, podemos pensar que todas estas variantes gráficas y visuales que hemos analizado no son consecutivas en el tiempo, sino que se han complementado o alternado históricamente y cognitivamente. Pues, salvando el anacronismo, de alguna manera muchas de las disposiciones que pusieron en movimiento los mapas callejeros están presentes en nuestra propia memoria espacial de la ciudad. Por una parte, una imagen difusa de un centro amplio, pero a la vez compacto y uniforme (ese que se dispone en la página de los Mulhall). Por otra parte, una ciudad que tiene acentos, destacados, como en el mapa de Ritter; en efecto, a la manera de las barras que van organizando el espacio de los compases en las partituras, y que nos permiten recordar y repetir, los "ejes divisorios" no son necesariamente ejes viales de mayores dimensiones en lo material, pero están de todos modos inscriptos en nuestras imágenes mentales como acentos que escanden la trama, que sin ellos se vuelve imposible de comprender y organizar en la imaginación. Finalmente, una ciudad con volumen en el plano mural de 1895, que tiene un detallado foco central y una periferia que se torna borrosa hacia un horizonte imposible, en una perspectiva que es a la vez un juego óptico. Y que, de tan inmensa, sugiere una porción de nuestra curva superficie planetaria.

¿Cuánto de esta historia de imágenes materiales y mentales circula en el nuevo tiempo de los mapas para el movimiento? El mapa que desde las pantallas, con escala indefinida, variable y ajustable, que se acerca y aleja a nuestra voluntad, que se reorienta según nuestro movimiento en los GPS al punto de perder "el norte”, propone recorridos sin "curaduría” previa, sin los consejos de las guías -aunque no conviene olvidar 
las “áreas de interés" de Google Maps, establecidas con misteriosos y protegidos algoritmos-, sin vincularlos con los otros componentes que dan vida y orden a la ciudad y a nuestra propia percepción y constitución como habitantes citadinos. Se trata, ciertamente, de un momento de profunda transformación, en el que será interesante presenciar cómo se van definiendo nuevas modalidades visuales para mapear, discurrir y vivir en la ciudad.

\section{REFERENCIAS}

Almanaque Nacional y Guia del Comercio para 1870 publicado por la Imprenta del Siglo. Buenos Aires: Imprenta del Siglo.

Almanaque Peuser para el año de 1888 dirigido por Enrique Ortega. Buenos Aires: Jacobo Peuser.

Ares, F. (Comp) (2018). En torno a la imprenta de Buenos Aires (1780-1940). Buenos Aires: Patrimonio de Buenos Aires.

Bagrow, L. (1966). History of Cartography. Revised and augmented by R. A. Skelton. Londres: Watts \& Co. Ltd.

Coni, P. E. (1868). Almanaque popular para el año bisiesto del Señor 1868. Recuperado de http:// repositorio.anh.org.ar/jspui/handle/anh/160.

Corner, J. (1999). The Agency of Mapping: Speculation, Critique and Invention. En D. Cosgrove (Ed.). Mappings (pp. 213 - 252). Londres: Reaktion Books.

Cosgrove, D. (Ed.).(1999). Mappings. Londres: Reaktion Books.

Costa, M. E. (2018). Los talleres multigráficos de Guillermo Kraft y Jacobo Peuser en los inicios de la industria editorial argentina. En A. Fabio (Comp.) En torno a la imprenta de Buenos Aires (1780-1940) (pp. 179-228). Buenos Aires: Patrimonio de Buenos Aires.

Cuéllar Wills, L. (2014). Territorios en papel: las guías de forasteros en Hispanoamérica (1760-1897). Fronteras de la Historia, 19(2), 176-201. Recuperado de https://revistas.icanh.gov.co/index.php/fh/article/view/197.

Edney, M. H. (2019). Cartography. The Ideal and its history. Chicago: The University of Chicago Press.

Favelukes, G., Gómez Pintus, A. y Novick, A. (2019). Figuraciones del suburbio. Mapas comerciales y expansión metropolitana en el Gran Buenos Aires, 1940-1950. EGA Revista de Expresión Gráfica Arquitectónica, 37, $156-$ 167. doi: https://doi.org/10.4995/ega.2019.10952.

Gené, M. y Malosetti Costa, L. (Comps.) (2009). Impresiones porteñas. Imagen y palabra en la historia cultural de Buenos Aires. Buenos Aires: Edhasa.

Gluzman, G., Munilla Lacasay, L. y Szir, S. (2013). Género y Cultura Visual. AdrienneMacaire-Bacle en la historia del arte argentino. Buenos Aires (1828-1838). Artelogie, 5, 1-31. Recuperado de http://cral.in2p3.fr/artelogie /spip.php?article245.

Gómez Pintus, A. (2019). “Cómo transitar el Área Metropolitana de Buenos Aires. La guía Filcar de planos suburbanos de 1955. En AaVv (2019), Jornada 140 años en la cartografía argentina: Instituciones y sujetos en el quehacer cartográfico del pais. La Plata: HITEPAC, UNLP (mimeo).

González Bracco, M. (2017). "La construcción de una imagen turística para la ciudad de Buenos Aires en las guías de viaje de la primera mitad del siglo XX”. Nuevo Mundo Mundos Nuevos [en línea], Questions du temps présent, 0-16. doi: https://doi.org/10.4000/nuevomundo.71602.

Guia Kraft: comercial, industrial y profesional para el año 1889. Buenos Aires.

Harley, J. B. (2005). La nueva naturaleza de los mapas. Ensayos sobre historia de la cartografia. México: FCE.

Junior, C. y Stein, E. (1877). Buenos Aires Ilustrado. Almanaque Comercial y Guia de los Forasteros para 1877. Buenos Aires: Imprenta y Litografía del Courier de La Plata.

Kitchin, R. y Dodge, M. (2007). Rethinking maps. Progress in Human Geography, 31(3), 331-344. doi: https://doi. org/10.1177/0309132507077082. 
Lois, C. (2015). El mapa, los mapas. Propuestas metodológicas para abordar la pluralidad y la inestabilidad de la imagen cartográfica. Geograficando, 11(1). Recuperado de https://www.geograficando.fahce.unlp.edu.ar/a.

Mendoza Vargas, H. (2016). Las guías urbanas: imagen e invención del espacio de la ciudad de México. Investigaciones Geográficas 89: 90-106. doi: https://doi.org/10.14350/rig.47648.

Morcrette, Q. (2015). Traverserla surface. Terra Brasilis(NovaSérie) 6: 2-21. Recuperado de http://terrabrasilis.rev ues.org/1676.

Mulhall, M. G. y Mulhall, E. T. (1863). Introducción. En Autores (Eds.) The River Plate Hand-book, Guide, Directory and Almanac for 1863, comprising the City and Province of Buenos Ayres, the other Argentina provinces, Montevideo, etc. Buenos Aires: The Editors of the Standard.

Mulhall, M. G. y Mulhall, E. T. (1876). Manual de las repúblicas del Plata. Buenos Aires y Londres: Imprenta Especial para obras de P. Coni-Imprenta del "Standard"-Edward Stanford

Mulhall, M. G. y Mulhall, E. T. (1892). Handbook of the River Plate, comprising the Argentine Republic, Uruguay and Paraguay. 6a edición. Buenos Aires: Standard Court-Kegan Paul-Teench\& Co.

Novick, A.y Favelukes, G. (2019). As bordas da região de Buenos Aires. Algumashipóteses de trabalho para a construção de histórias de longo prazo. Urbana: Revista Eletrônica do Centro Interdisciplinar de Estudos sobre a Cidade 11(1): 7-41.

Palsky, G. (1998). Origines et évolution de Ia Cartographie Thématique (XVIIe -XIXe siècles). Revista Da Faculdade de Letras -Geografia, Porto, XIV, 39-60.

Solveyra, W. (1862). El avisador, guia general de comercio y de forasteros. Buenos Aires: Imprenta argentina de "El Nacional".

Szir, S. M. (2018). El fabricante de imágenes. César Hipólito Bacle y el establecimiento de la litografía en Buenos Aires (1828-1838). En F. Ares (Comp) En torno a la imprenta de Buenos Aires (1780-1940) (pp. 105-134). Buenos Aires: Patrimonio de Buenos Aires.

Szir, S. M. (2017). Imágenes y tecnologías entre Europa y la Argentina. Migraciones y apropiaciones de la prensa en el siglo XIX. Nuevo mundo mundos nuevos. https://doi.org/10.4000/nuevomundo.70851.

Taullard, A. (1940). Los planos más antiguos de Buenos Aires, 1580-1880. Buenos Aires: Peuser.

Thrower, N. (1996). Maps and civilization. Cartography in culture and society. Chicago y Londres: The University of Chicago Press.

Verdier, N. (2011). Les formes du voyage\#: cartes et espaces des guides de voyage. In Situ, 15, 0-18. https://doi.org /10.4000/insitu. 573 .

Ware, W. R. (1882). Modern perspective: a treatise upon the principles and practice of plane and cylindrical perspective. Boston: Ticknor \& Company.

\section{Notas}

1 Este artículo ha sido realizado en el marco del proyecto UBACYT "Materiales para un atlas de la región metropolitana de Buenos Aires 2. Las formas del territorio", dirigido por Graciela Favelukes y codirigido por Alicia Novick, dentro del Programa de Historia Urbana y Territorial, Instituto de Arte Americano, Universidad de Buenos Aires, código 20020170100569BA.

2 Como indicaba la presentación de la guía de Wenceslao Solveyra (1862): "Este libro ha sido aceptado por los Gobiernos, nacional, provincial, la municipalidad, el comercio y la prensa ilustrada de Buenos Aires, entre ellos los redactores de los diarios La Tribuna, El Nacional y La Revista. La primera edición fue de 6000 volúmenes y el Gobierno del General Mitre cooperó suscribiéndose a 100 ejemplares" (p. 2). Buenos Aires contaba en esos años con una población cercana a los 170.000 habitantes: un cálculo apenas indicativo sugiere una distribución de un ejemplar de la guía cada 30 habitantes.

3 Principalmente, el Plano Topográfico de 1867 en 1:8.000, publicado por el Departamento Topográfico de la Provincia de Buenos Aires en 1867 (https://gallica.bnf.fr/ark:/12148/btv1b53098699s), y más tarde el plano topográfico en 1:10.000 publicado por la Municipalidad porteña en 1895 (https://catalogo.bn.gov.ar/F/?func=direct\&doc_number $=000280123 \&$ local_base $=$ GENER). 
4 Recordemos que el ancho general de las calles de la traza fundacional era de 11 varas. La normativa de los años 1820 estableció que algunas calles de dirección este-oeste, entre ellas Rivadavia, pasarían a tener 20 varas de ancho, al igual que Callao-Entre Ríos, pero esto no se aplicaba a las divisorias de nomenclatura.

5 El plano se conserva en la Biblioteca Nacional de Francia. Aunque está archivado como lámina suelta, es posible que haya formado parte de una guía de viaje, pues su tamaño es adecuado para la encuadernación y plegado $(25 \times 40 \mathrm{~cm})$. No es raro que los mapas estén archivados como piezas aisladas, a pesar de haber formado parte originalmente de libros encuadernados, algo que se puede vincular con los circuitos y prácticas del coleccionismo y comercio de mapas. 